\title{
A case of primary lung cancer producing alpha-fetoprotein
}

Toshiyuki Yamagata MD PhD ${ }^{1,2}$, Yuko Yamagata MD PhD², Masanori Nakanishi MD PhD², Kazuto Matsunaga MD PhD², Yoshiaki Minakata MD PhD², Masakazu Ichinose MD PhD²

T Yamagata, Y Yamagata, M Nakanishi, K Matsunaga, Y Minakata, M Ichinose. A case of primary lung cancer producing alpha-fetoprotein. Can Respir J 2004;11(7):504-506.

A case of lung carcinoid showing elevated plasma alpha-fetoprotein (AFP) level is reported. A 44-year-old man who complained of the development of bloody sputum had a left hilar lung mass on chest radiograph. The serum level of AFP was markedly increased to $8438 \mathrm{ng} / \mathrm{mL}$. After resection, it was diagnosed as an atypical carcinoid, and the tumour cells were positive for cytoplasmic AFP. AFP is one of the most useful tumour markers for the diagnosis of hepatic cell carcinoma or germ cell tumours. It has also been reported that some primary lung tumours produce AFP. However, these tumours are mainly poorly differentiated adenocarcinomas or large cell carcinomas. A lung carcinoid that produces AFP is extremely rare.

Key Words: Alpha-fetoprotein; Atypical carcinoid; Lung tumour

\section{Un cas de cancer pulmonaire primaire produisant des alpha-fotoprotéines}

\begin{abstract}
Un cas de carcinoïde pulmonaire associé à un taux élevé d'alphafœetopréines (AFP) plasmatique est déclaré. Un homme de 44 ans qui se plaignait d'expectorations hémoptoïques présentait une masse pulmonaire hilaire gauche à la radiographie thoracique. Le taux sérique d'AFP était beaucoup plus élevé qu'à l'habitude, à $8438 \mathrm{ng} / \mathrm{mL}$. Après la résection, on a diagnostiqué un carcinoïde atypique, et les cellules tumorales étaient positives à l'AFP cytoplastique. L'AFP est l'un des marqueurs tumoraux les plus utiles pour diagnostiquer un carcinome des cellules hépatiques ou des tumeurs des cellules germinales. Il a déjà été déclaré que certaines tumeurs pulmonaires primaires produisent de l'AFP. Cependant, ces tumeurs sont surtout des adénocarcinomes mal différenciés ou des carcinomes à grandes cellules. Il est d'une extrême rareté qu'un carcinoïde pulmonaire produise de l'AFP.
\end{abstract}

A lpha-fetoprotein (AFP) is one of the most useful tumour markers for the diagnosis of hepatic cell carcinomas (HCC) or germ cell tumours (1). Therefore, if an elevation of serum AFP levels is found with a lung tumour, it is likely to be a metastatic lung tumour due to HCC. Although it has been previously reported (2-5), a primary lung tumour that produces AFP is quite rare. To our knowledge, there has only been one case of a lung carcinoid producing AFP reported in the literature (6). We report a case of lung atypical carcinoid that produced AFP and had a good clinical course after operative resection.

\section{CASE PRESENTATION}

A 44-year-old man who complained of the development of bloody sputum had a left hilar mass on chest radiograph (Figure 1). He lost $11 \mathrm{~kg}$ of weight in one month. He had a history of smoking (20 cigarettes/day for 25 years).

On physical examination, there were no apparent abnormal findings. No abnormalities indicating liver disease were apparent in hematology or blood chemistry. Serological tests for hepatitis $\mathrm{B}$ and $\mathrm{C}$ were negative. Among the various tumour markers, only AFP was markedly increased to $8438 \mathrm{ng} / \mathrm{mL}$ (normal values less than $3.5 \mathrm{ng} / \mathrm{mL}$ ). No other tumour markers, such as carcinoembryonic antigen, squamous cell carcinoma associated antigen, cytokeratin-19 fragments, neuron-specific enolase or progastrin releasing peptide, were elevated. In addition, the lens culinaris agglutinin A-reactive fraction of alpha-fetoprotein, usually a useful marker for HCC, was $86.5 \%$.

In a chest computed tomography scan, the mass was located just behind the descending aorta (Figure 2). There was no hilar

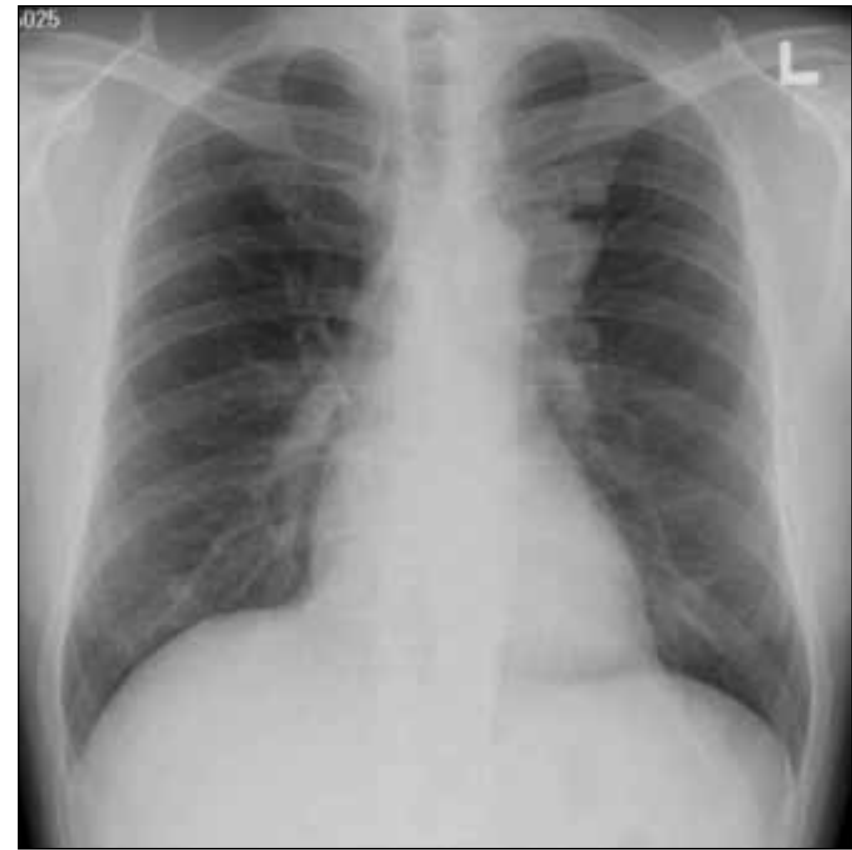

Figure 1) A chest radiograph showing the mass at the left hilum of the lung

or mediastinal lymphadenopathy. On fiberoptic bronchofiberscopy, the left upper lobe bronchus was almost obstructed by a dark red polypoid tumour. The mass was diagnosed as nonsmall cell carcinoma by transbronchial biopsy. There was no

${ }^{1}$ Division of Clinical Oncology and Palliative Medicine; ${ }^{2}$ Third Department of Internal Medicine, Wakayama Medical University, Wakayama, Japan Correspondence and reprints: Dr Toshiyuki Yamagata, Third Department of Internal Medicine, Wakayama Medical University, 811-1, Kimiidera, Wakayama-City, Wakayama, 641-0012 Japan. Telephone 81-73-441-0619, fax 81-73-446-2877, e-mail y-toshi@wakayama-med.ac.jp 


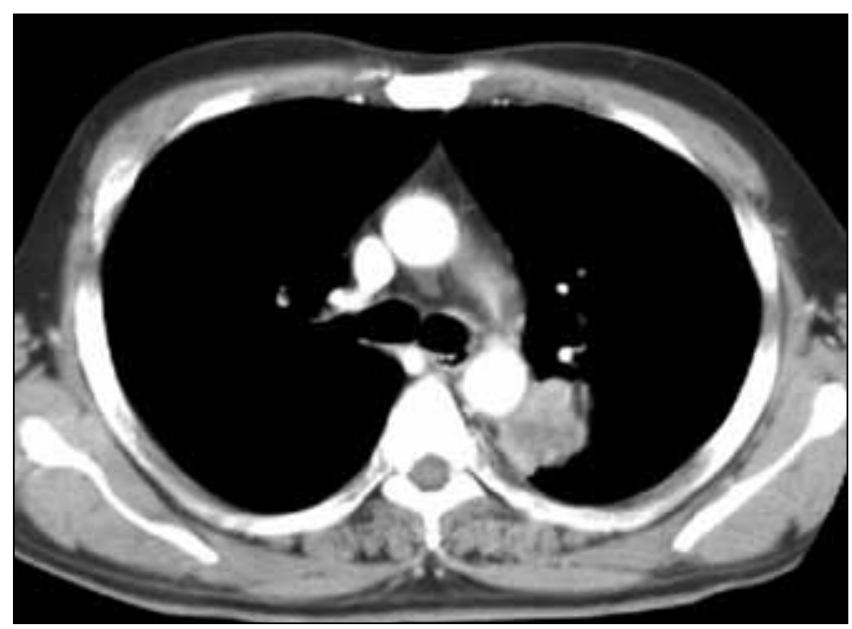

Figure 2) In a chest computed tomography scan, the mass was approximately $3 \mathrm{~cm}$ in diameter and rather heterogeneous, located just behind the descending aorta. There was no swelling of hilar or mediastinal lymph nodes

evidence of HCC, liver cirrhosis or any other liver disorder on the abdominal computed tomography scan or ultrasonograph. On the TNM ( $\mathrm{T}$ tumour; $\mathrm{N}$ regional lymph nodes; and $\mathrm{M}$ distant metastasis) staging system, the patient was classified as being clinical T2NOMO and at stage IB.

The patient underwent a successful left upper lobectomy. The resected tumour was $3.5 \mathrm{~cm} \times 3.3 \mathrm{~cm}$ in size. Histopathologically, the resected lung mass showed infiltration of round uniform tumour cells with partial formation of rosettes and pseudoglandular ducts. No tumour cells were detected in any resected lymph nodes. Necrosis of tumour cells in a punctuate distribution was also seen (Figure 3). Tumour cells had round and various sized nuclei with the chromatin forming small clumps. There was increased nuclear division with seven to eight mitoses per 10 high-power fields. There were also prominent nucleoli. Immunohistochemically, these tumour cells were positive for AFP in the cytoplasm (Figure 4). Tumour cells were also positive for chromogranin A, a useful immunohistochemical marker for carcinoids, glucagon and vasoactive intestinal polypeptides, and negative for synaptophysin, serotonin, gastrin, adrenocorticotropic hormone and insulin. From these findings, the present case was diagnosed as a lung atypical carcinoid producing AFP. The serum level of AFP markedly decreased to $61.8 \mathrm{ng} / \mathrm{mL}$ and then to the normal range $(3.3 \mathrm{ng} / \mathrm{mL})$ at one month and three months after resection, respectively. The patient has been symptom free for over two years and no elevation of serum level of AFP has been observed.

\section{DISCUSSION}

AFP was first reported in 1965 (7) and is one of the most useful tumour markers for the diagnosis of HCCs or germ cell tumours. This tumour marker has been a reliable diagnostic tool for these tumours. However, the report of a case of primary lung cancer producing AFP is quite rare. Naturally, it is sometimes seen that a metastatic lung tumour from HCC can produce AFP. Therefore, elevation of the serum level of AFP would first lead to suspected HCC or germ cell tumour metastasis rather than primary lung cancer. However, there have been several cases of primary lung cancer producing AFP reported previously. The first case reported in the literature was in 1972 (2). Subsequently, there have been several case reports (primarily reported by Japanese clinicians). Okunaka et al (3) have reported only

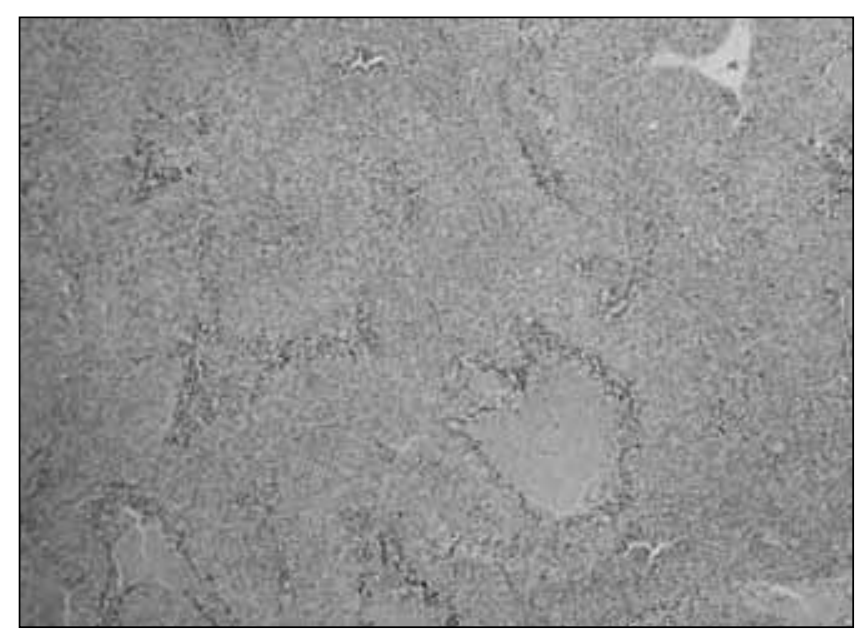

Figure 3) Histopathologically, the resected tumour showed punctate necrosis and infiltration of round uniform tumour cells

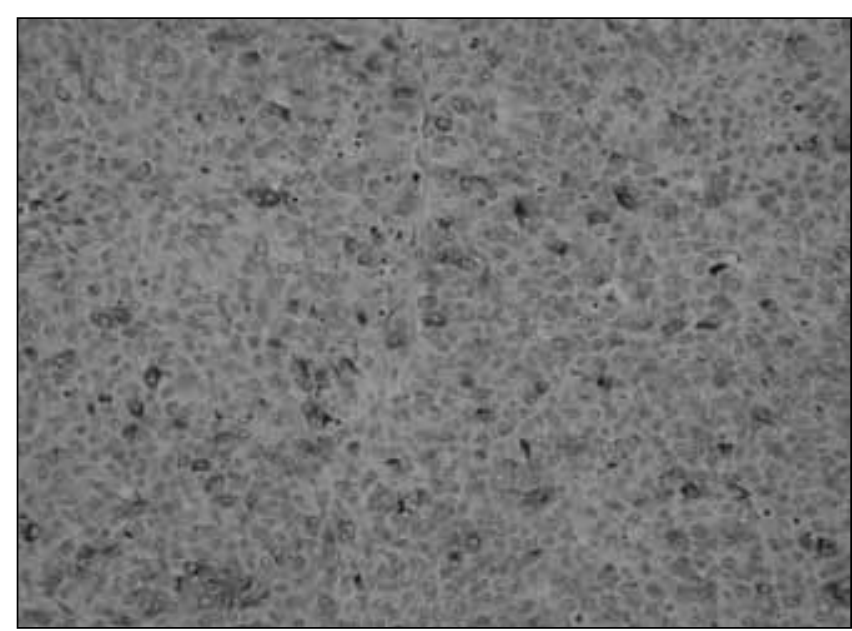

Figure 4) Immunohistochemically, these tumour cells were positive for alpha-fetoprotein in the cytoplasm. Tumor cells had round and various sized nuclei. An increase in nuclear division was detected

24 cases of AFP-producing lung cancer without liver metastasis. Although some other cases have been described (5), primary lung cancer producing AFP is still quite rare.

Histologically, AFP-producing lung cancer mostly shows adenocarcinoma occurring in approximately $65 \%$ of cases, followed by large cell carcinoma ( $25 \%$ of cases). A few cases of small cell carcinoma or squamous cell carcinoma have also been reported (8). In adenocarcinoma, over one-half of the cases are poorly differentiated carcinoma. These findings suggest that cancer cells producing AFP have a higher degree of undifferentiation, which suggests these cells may be derived from primitive fetal tissue.

Lung carcinoid is a relatively rare, primary lung tumour comprising approximatey $5 \%$ of all lung tumours (9). Lung carcinoids often secrete several tumour markers, such as carcinoembryonic antigen and neuron-specific enolase (10). However, production of AFP is quite rare, with only one case reported thus far in the literature (6).

In the present case, the serum level of AFP increased to over $8000 \mathrm{ng} / \mathrm{mL}$, with no elevation of other tumour markers. In addition, AFP in the tumour cells was observed with 
immunohistochemical staining of the resected lung tissue. Thus, the present case was diagnosed as a very rare case of atypical AFP-producing lung carcinoid. AFP is largely produced and secreted by the cells in the liver and the yolk sac during the embryonic period. Therefore, there is the possibility that ectopic liver or germ cells in the lung might have been the source of the AFP (11). It is also possible that respiratory epithelium per se might produce AFP (11). Because most lung tumours producing AFP are poorly differentiated adenocarcinoma and large cell carcinoma, it may be that these undifferentiated cells of several derivations have the potential to produce AFP.

\section{REFERENCES}

1. Gitlin D, Perricelli A, Gitlin GM. Synthesis of alpha-fetoprotein by liver, yolk sac, and gastrointestinal tract of the human conceptus. Cancer Res 1972;32:979-82.

2. Corlin RF, Tompkins RK. Serum alpha 1-fetoglobulin in a patient with hepatic metastases from bronchogenic carcinoma. Am J Dig Dis 1972;17:553-5.

3. Okunaka T, Kato H, Konaka C, Yamamoto H, Furukawa K. Primary lung cancer producing alpha-fetoprotein. Ann Thorac Surg 1992;53:151-2.
4. Yoshino I, Hayashi I, Yano T, Takai E, Mizutani K, Ichinose Y. Alpha-fetoprotein-producing adenocarcinoma of the lung. Lung Cancer 1996;15:125-30.

5. Hiroshima K, Iyoda A, Toyozaki T, et al. Alpha-fetoproteinproducing lung carcinoma: Report of three cases. Pathol Int 2002;52:46-53

6. Ohtsuki H, Midorikawa O, Okada H, Morikawa S, Sakaguchi H. Pulmonary atypical carcinoid tumor with marked alpha-fetoprotein production and features of an adenocarcinoma differentiation. Pathol Res Pract 1988;184:86-97.

7. Tatarinov YS. Content of embryo-specific alpha-globulin in fetal and neonatal sera and sera from adult humans with primary carcinoma of the liver. Fed Proc Transl Suppl 1966;25:344-6.

8. Asamura $\mathrm{H}$, Nakayama $\mathrm{H}$, Kondo $\mathrm{H}$, et al. AFP-producing squamous cell carcinoma of the lung in an adolescent. Jpn J Clin Oncol 1996;26:103-6.

9. Paladugu RR, Benfield JR, Pak HY, Ross RK, Teplitz RL. Bronchopulmonary Kulchitzky cell carcinomas. A new classification scheme for typical and atypical carcinoids. Cancer 1985;55:1303-11.

10. Carcinoid tumor. In: Fraser RS, Muller NL, Colman NC, Pare PD, eds. Diagnosis of Diseases of the Chest. Philadelphia: WB Saunders, 1999:1229-43.

11. Ishikura H, Kanda M, Ito M, Nosaka K, Mizuno K. Hepatoid adenocarcinoma: A distinctive histological subtype of alphafetoprotein-producing lung carcinoma. Virchows Arch A Pathol Anat Histopathol 1990;417:73-80. 


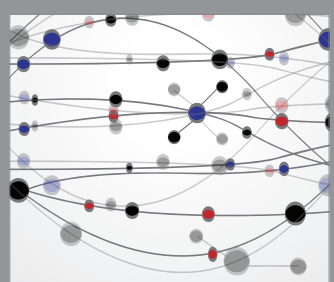

The Scientific World Journal
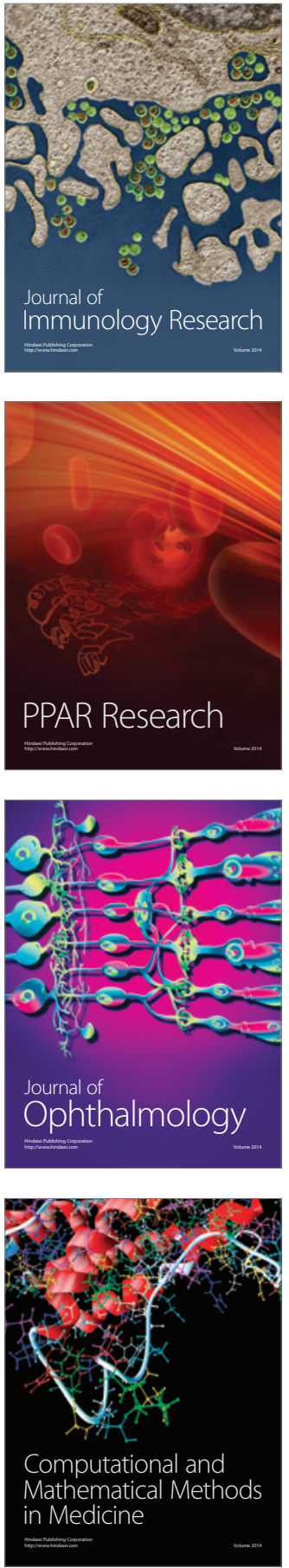

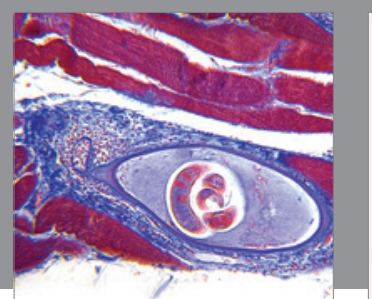

Gastroenterology Research and Practice

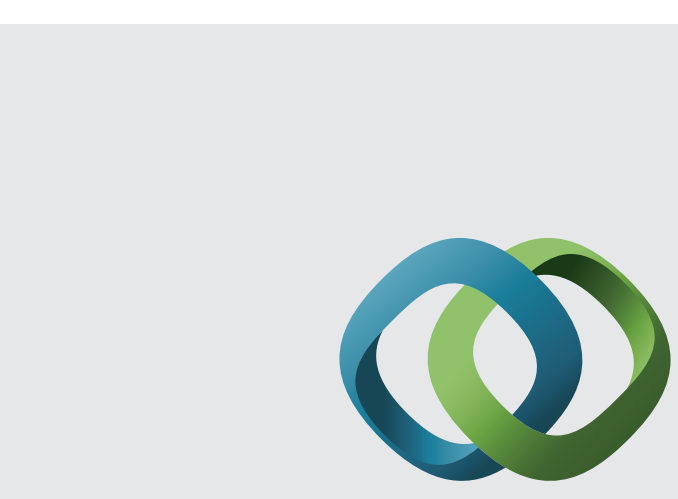

\section{Hindawi}

Submit your manuscripts at

http://www.hindawi.com
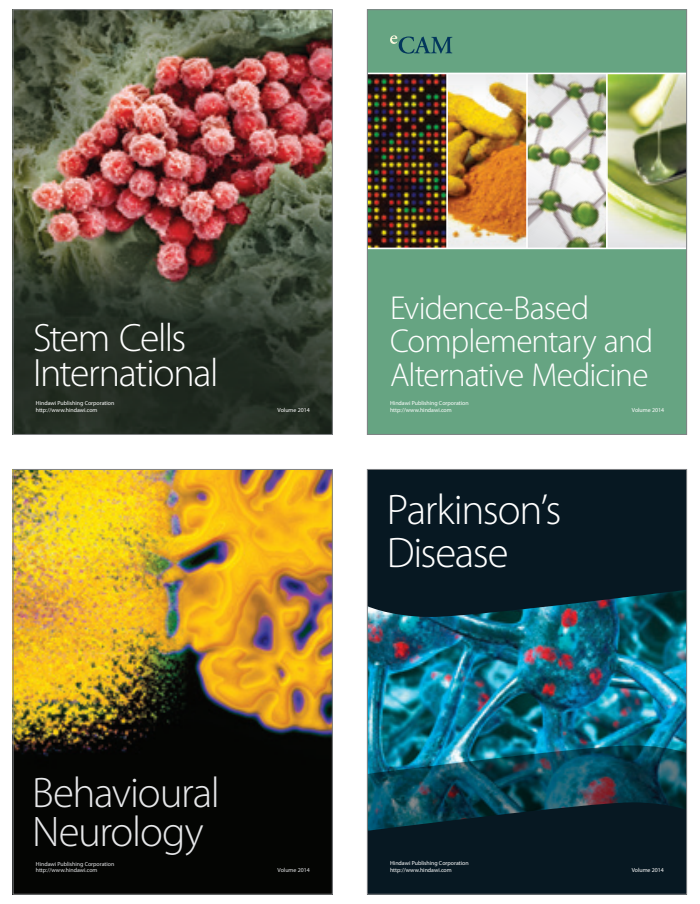
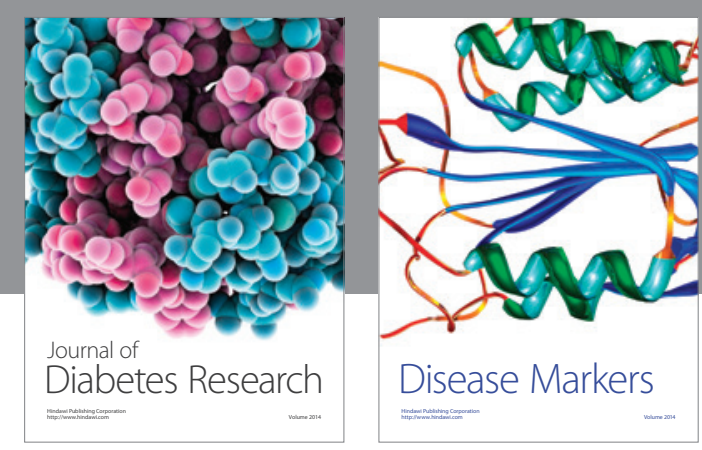

Disease Markers
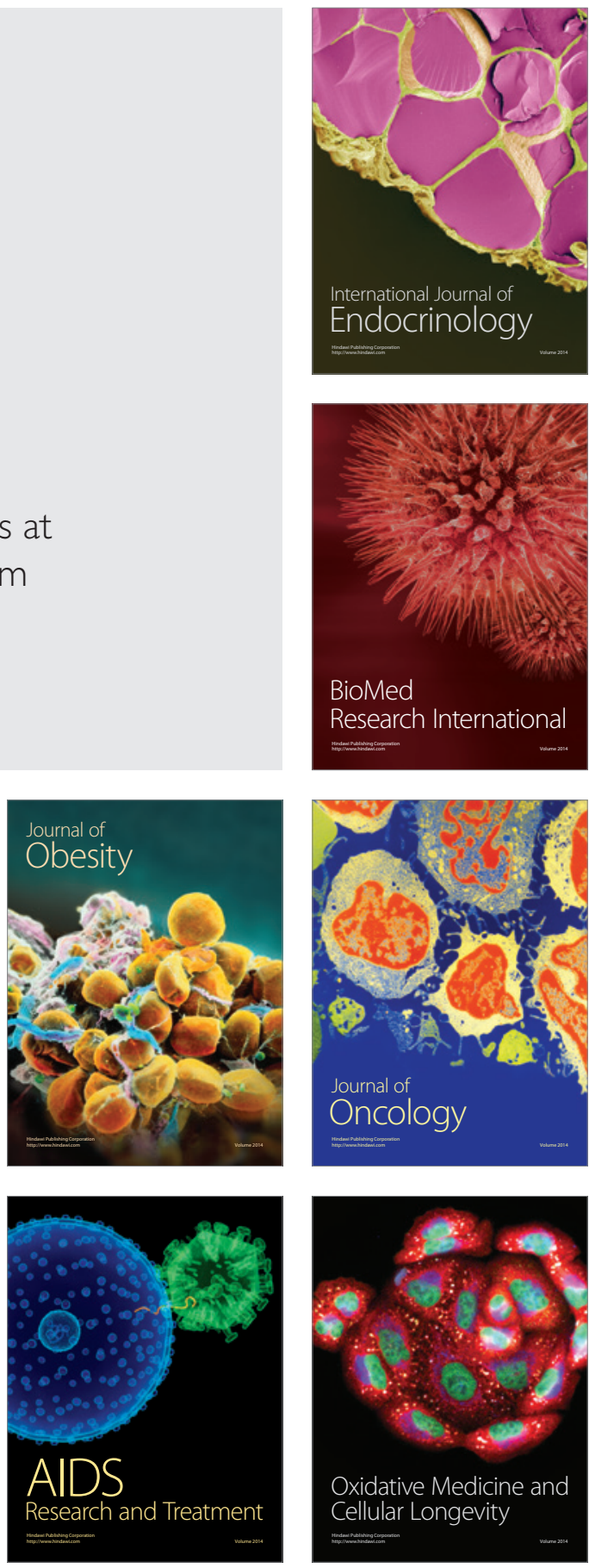